\title{
Carbon, nitrogen and phosphorus budgets of silver carp Hypophthalmichthys molitrix with the co-culture of grass carp Ctenopharyngodon idella
}

\author{
Bin Xia ${ }^{1,2}$, Zhenlong Sun ${ }^{1}$, Qin-Feng Gao ${ }^{1, *}$, Shuanglin Dong ${ }^{1}$, Fang Wang ${ }^{1}$ \\ ${ }^{1}$ Key Laboratory of Mariculture, Ministry of Education, Ocean University of China, Qingdao, Shandong 266003, PR China \\ ${ }^{2}$ Marine Science and Engineering College, Qingdao Agricultural University, Qingdao, Shandong 266109, PR China
}

\begin{abstract}
Fish farming activities have resulted in increasing nutrient pollution and subsequent deterioration of water quality in aquatic environments worldwide. Silver carp Hypophthalmichthys molitrix can efficiently remove excessive nutrient pollution by filtering the suspended particulate organic matter. To evaluate the feasibility and capacity of using silver carp as biofilters to remove the wastes released from the farming of grass carp Ctenopharyngodon idella, 3 mesocosms comprising grass carp and silver carp were developed. Carbon $(\mathrm{C})$, nitrogen $(\mathrm{N})$ and phosphorus $(\mathrm{P})$ budgets of silver carp were measured every month from May to October in 2011. Owing to the changes in exogenous environmental conditions and autogenous physiological status such as water temperature, dissolved oxygen level and feeding behavior, the metabolic acquisition and expenditure of silver carp exhibited obvious temporal fluctuation. For a standardized silver carp with $30 \mathrm{~cm}$ body length, the average scope for growth of $\mathrm{C}, \mathrm{N}$ and $\mathrm{P}$ were 54.83, 8.73 and $0.85 \mathrm{mg}$ $\mathrm{h}^{-1}$, respectively. Total nutrient assimilation capacities throughout the experimental period for $\mathrm{C}, \mathrm{N}$ and $\mathrm{P}$ were 236.86, 37.70 and $3.67 \mathrm{~g}$, respectively. Our findings show that silver carp with the coculture of grass carp provides an economic and environmental win-win resolution to enhance aquaculture production and reduce organic pollution in water.
\end{abstract}

KEY WORDS: Silver carp · Grass carp · Biofiltration · Nutrient budget $\cdot$ Pollution · Fish farming

\section{INTRODUCTION}

The depletion of aquatic resources has stimulated the development of aquaculture worldwide. Meanwhile, the environmental risk of fish farming effluents is well recognized, especially in intensive aquaculture with high farming density and substantial supply of artificial feed (Muir 1982, Kestemont 1995, Gao et al. 2005, Xia et al. 2013c). Ackefors \& Enell (1994) estimated that $78 \mathrm{~kg}$ nitrogen $(\mathrm{N})$ and $9.5 \mathrm{~kg}$ phosphorus (P) per ton of fish production, on average, were released to the water column when the feed conversion coefficient is 1.5 . Approximately $72 \% \mathrm{~N}$ and $70 \% \mathrm{P}$ in feed were not retained by fish, which could become nutrient pollution in forms of uneaten pellets, feces and excretion. Untreated wastewater that is continuously discharged into aquatic environ-

\footnotetext{
*Corresponding author: qfgao@ouc.edu.cn
}

ment could cause remarkable elevation of organic matters (Cao et al. 2007). Dissolved and particulate organic nutrients might provide an energy source for suspension feeders or an uptake source through membranes of multicellular and particularly unicellular organisms. However, the elevated inorganic nutrient loadings from decomposition of wasted feed and fish excreta could be cell-toxic in the case of $\mathrm{N}$ compounds, and stimulate toxic algae blooms, resulting in mass mortality of cultured species and subsequent economic loss.

Measures for reducing the negative impacts of aquaculture on the environment have become a major concern for the sustainable development of aquaculture (Gowen et al. 1990, Lin \& Yi 2003, Pillay 2007). The high nutrient content of the suspended feed residues and other particulate organic matters in fish 
farming effluents may be a potential food source for suspension-feeding organisms (Gophen et al. 2003). In an integrated ecosystem combining fish and suspension-feeding organisms, the 'biofilters' can utilize the organic wastes as food sources, and the nutrient content in the organic matters is thus ingested and accumulated in the tissues of the organism instead of being dissolved in the water column or deposited on the sediment, which provides an economic and environmental win-win resolution scheme (Xie \& Liu 2001, Gao et al. 2006, Yan et al. 2009).

Grass carp Ctenopharyngodon idella is the most commercially important freshwater fish species for aquaculture in China (MOAC 2013). Its production has increased rapidly over recent decades (Xia et al. 2013a, 2013b). However, the high stocking density with an artificial supply of formulated feed has resulted in a large amount of effluents. Silver carp Hypophthalmichthys molitrix, a typical suspensionfeeding fish (Dong et al. 1992, Kadir et al. 2006), has drawn much attention worldwide because of its potential application for removing farming wastes without secondary pollution (Smith 1989, Starling 1993, Fukushima et al. 1999, Tucker 2006, Ke et al. 2007). It plays a positive role in improving the fish-farming environment (Burke et al. 1986, Starling \& Rocha 1990). Chen et al. (1991), for example, reported that feeding by silver carp took $3.01 \%$ and $5.28 \%$ of the total $\mathrm{N}$ and $\mathrm{P}$, respectively, out of the water in the Wuhan East Lake ecosystem. In spite of the ecological function of silver carp, metabolic acquisition and expenditure of nutrients including carbon $(\mathrm{C}), \mathrm{N}$ and $\mathrm{P}$ by this species have not been examined so far. In the present study, co-culture systems combining grass carp and silver carp were developed, and temporal changes in $\mathrm{C}, \mathrm{N}$ and $\mathrm{P}$ budgets of silver carp were examined so as to evaluate the feasibility and capacity of using silver carp as a biofilter to reduce nutrient pollution in grass carp ponds.

\section{MATERIALS AND METHODS}

\section{Study area and experimental set-up}

The experimental pond for fish culture was located in Jinan City, Shandong Province, China (36 69' N, $\left.116^{\circ} 86^{\prime} \mathrm{E}\right)$. The freshwater used in the pond was pumped from a nearby well. The pond area was approximately 5 ha, with water depth ranging from 1.6 to $1.7 \mathrm{~m}$. Three replicate enclosures of the same size $(\mathrm{L} \times \mathrm{W} \times \mathrm{D}=8 \times 8 \times 2.5)$, which divided the culture pond into different parts, were constructed within the pond. The enclosures were made of waterproof polyvinyl plastics with supporting timber piles around the boundaries of the enclosures. The separation of the pond area by enclosures avoided the water exchange between different experimental treatments. Juvenile grass carp and silver carp with body mass of $\sim 100 \mathrm{~g}$ and mass proportion of 3:1 were released to the enclosures in March. The fish stocking density was 1 individual per square meter. Artificial feed was supplied to the grass carp with the ration of $5 \%$ total grass carp biomass daily. The main ingredients of the feed consisted of $28 \%$ protein, $6 \%$ fat and $33 \%$ carbohydrate. The experiment lasted for 6 months from May to October 2011.

\section{Physiological measurements and standardizations}

The filtration was determined in situ via an indirect biodeposition method in a flow-through system on the bank of the pond. Three silver carp from each enclosure were randomly collected to determine biofiltration capacity at monthly intervals. Each individual silver carp was kept in a separate aquarium ( 25 l) and supplied with continuously flow-through water pumped from a larger aquarium ( 75 1), which was used as a reservoir (Fig. 1). Three other flow-through systems without animals were used as controls. The water in the reservoir was pumped from the corresponding enclosure in the pond. The particles in the reservoir were kept in suspension by aeration and stirring. A preliminary experiment that was conducted to determine the appropriate flow rate used in the experiment showed that the reduction in particle

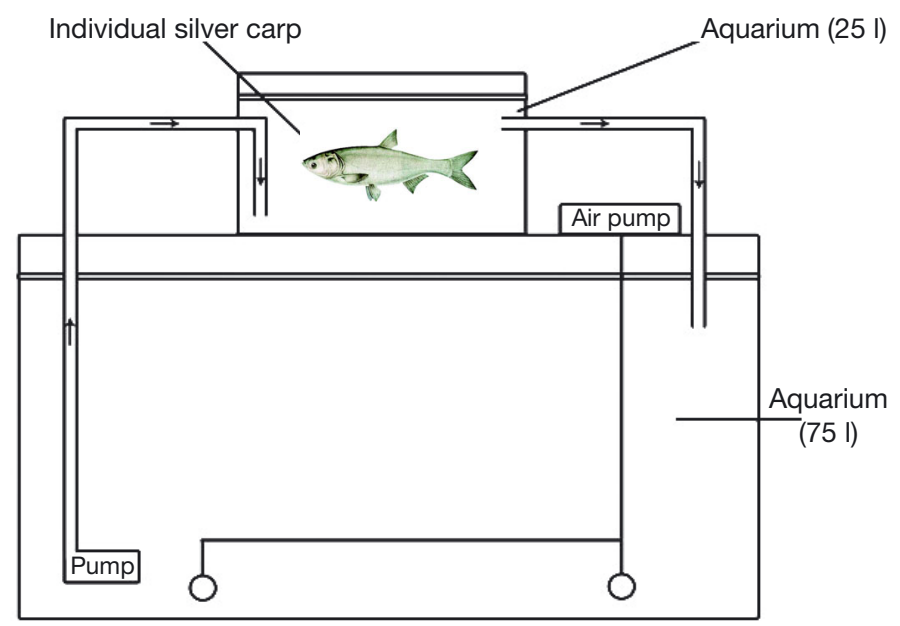

Fig. 1. Flow-through system used to determine the filtration of silver carp Hypophthalmichthys molitrix in situ via an indirect biodeposition method 
concentration at a flow rate of $51 \mathrm{~min}^{-1}$ was less than $20 \%$. The $20 \%$ reduction in the particle concentration between inflow and outflow water did not obviously affect the feeding of silver carp. Measures were taken to minimize environmental stress on silver carp such as acclimation and shading.

Silver carp were cultured for 1 to $2 \mathrm{~h}$, depending on the amount of feces collected. The collected water samples were filtered using glass fiber filters (Whatman GF/F) that were pre-combusted at $450^{\circ} \mathrm{C}$ for $6 \mathrm{~h}$ to remove any possible contamination of organic matter. The vacuum filtration was conducted under the suction of less than one-third atmospheric pressure to avoid the cell damage of phytoplankton. The filter papers were then dried in an oven at $80^{\circ} \mathrm{C}$ for $24 \mathrm{~h}$, weighed to the nearest $0.1 \mathrm{mg}$, ashed in a muffle furnace at $450^{\circ} \mathrm{C}$ and reweighed to determine total particulate matter (TPM; $\mathrm{mg} \mathrm{l}^{-1}$ ), particulate organic matter (POM; $\mathrm{mg} \mathrm{l}^{-1}$ ), particulate inorganic matter (PIM; $\mathrm{mg} \mathrm{l}^{-1}$ ) and organic content ( $f=$ POM/TPM).

Fish feces were cautiously collected with a pipette, avoiding resuspension of the fecal pellets. Total feces egestion $\left(E \mathrm{mg} \mathrm{h}^{-1}\right)$, organic matter egestion (OER; $\mathrm{mg} \mathrm{h}^{-1}$ ) and inorganic matter egestion (IER; $\mathrm{mg} \mathrm{h}^{-1}$ ) were determined by the same method described for the water samples.

Assuming that absorption of inorganic matter through the digestive system is negligible (Cranford \& Grant 1990, Turker et al. 2003), clearance rate (CR; $\left.1 \mathrm{~h}^{-1}\right)$, which is defined as the volume of water cleared per unit time, was then estimated as CR = IER/PIM. Filtration rate of TPM $\left(\mathrm{FR}_{;} \mathrm{mg} \mathrm{h}^{-1}\right)$, which is defined as the food mass filtered by silver carp per unit time, was computed as FR $=\mathrm{CR} \times \mathrm{TPM}$, and filtration rate of POM $\left(\mathrm{OFR}_{i} \mathrm{mg} \mathrm{h}^{-1}\right)$ as $\mathrm{OFR}=\mathrm{CR} \times \mathrm{POM}$. Hence, the food absorption rate $\left(A R_{;} m g h^{-1}\right)$ could be estimated as AR = OFR - OER, and absorption efficiency (AE) as $\mathrm{AE}=\mathrm{AR} / \mathrm{OFR}$.

Oxygen consumption and nutrient excretion of silver carp were determined after the filtration measurements. To determine oxygen consumption $\left(V_{\mathrm{O}_{2}}\right.$ i $\mathrm{mg} \mathrm{h}^{-1}$ ), each silver carp was placed in a sealed 501 polyethylene chamber (experimental chamber); 3 other empty chambers without silver carp served as control chambers. The sealed chambers were bathed in water to avoid the effect of temperature changes on the respiratory activities of the silver carp. After 0.5 to $1 \mathrm{~h}$, depending on the animal size, the DO levels of the experimental and control chambers were measured using the iodometry method. $V_{\mathrm{O}_{2}}$ was calculated using the following equation:

$$
V_{\mathrm{O}_{2}}=\left(\mathrm{DO}_{\mathrm{C}}-\mathrm{DO}_{\mathrm{E}}\right) \times v / t
$$

where $\mathrm{DO}_{\mathrm{C}}$ and $\mathrm{DO}_{\mathrm{E}}$ are the $\mathrm{DO}$ concentrations of the control and experimental chambers, respectively, $V$ is the volume of the chamber and $t$ is the experimental time.

For the tests of $\mathrm{N}$ and $\mathrm{P}$ excretion rates, the silver carp were maintained in separate polyethylene boxes for 0.5 to $1 \mathrm{~h}$, while 2 additional boxes without silver carp were used as controls. Results of previous studies showed that ammonium and phosphate are the predominant excretory products in teleosts (Ballestrazzi et al. 1998, Leung et al. 1999, Yang et al. 2002). Therefore, excretion rates of ammonium $\left(V_{\mathrm{N}} ; \mu \mathrm{g} \mathrm{h}^{-1}\right)$ and phosphate $\left(V_{\mathrm{P} i} \mu \mathrm{g} \mathrm{h} \mathrm{h}^{-1}\right)$ were determined using the Nessler's reagent and phosphor-molybdate colorimetric methods, respectively. $V_{\mathrm{N}}$ and $V_{\mathrm{P}}$ were calculated as follows:

$$
V_{\mathrm{N}}\left(\text { or } V_{\mathrm{P}}\right)=\left(C_{\mathrm{E}}-C_{\mathrm{C}}\right) \times v / t
$$

where $C_{\mathrm{E}}$ and $C_{\mathrm{C}}$ are the nutrient concentrations of the experimental and control boxes respectively, $v$ is the volume of the boxes and $t$ is the experimental time.

To facilitate comparisons of physiological rates (filtration, oxygen consumption and nutrient excretion) at different monthly intervals, physiological rates were size-standardized to the mean silver carp body length of $30 \mathrm{~cm}$ according to the following equation (Strychar \& MacDonald 1999):

$$
Y_{\mathrm{S}}=\left(X_{\mathrm{S}} / X_{\mathrm{O}}\right)^{b} \times Y_{\mathrm{O}}
$$

where $Y$ represents a physiological parameter and $X$ the body length $(\mathrm{cm})$ of silver carp, subscripts $\mathrm{S}$ and $O$ represent the standard and observed values, respectively, and $b$ is the power coefficient obtained from the respective monthly allometric equations relating physiological parameters with body length, i.e. $Y=a X^{b}$, where $a$ is the regression coefficient. Analysis of covariance (ANCOVA) indicated that the slopes of the monthly allometric equations were unequal (i.e. no all-time pooled slope might be regressed). Therefore, $b$ was the coefficient in the above allometric model derived from monthly data (Packard \& Boardman 1987).

\section{Nutrient analysis}

Water samples (200-300 $\mathrm{ml}$, depending on the concentration of particulate matter) were filtered through pre-combusted and weighed glass-fiber filters (Whatman GF/C) and dried at $80^{\circ} \mathrm{C}$ for $24 \mathrm{~h}$. Particulate organic carbon (POC; $\mu \mathrm{g} \mathrm{mg}^{-1}$ ) and particulate organic nitrogen $\left(\mathrm{PON} ; \mu \mathrm{g} \mathrm{mg}^{-1}\right.$ ) of seston 
were measured with a CHNS/O Analyzer (Vario EI), as were carbon and nitrogen contents of fecal pellets. Particulate organic phosphorus ( $\mathrm{POP} ; \mu \mathrm{g} \mathrm{mg^{-1 }}$ ) and total phosphorous content of fecal pellets were determined following the wet digestion method (Gao et al. 2008).

After collection, the silver carp samples were dried at $80^{\circ} \mathrm{C}$ for $2 \mathrm{~d}$ until constant weight. Nutrient $(\mathrm{C}, \mathrm{N}$ and $\mathrm{P}$ ) contents in the dried silver carp were determined using the method similar to that used to analyse fish feces. Production was then estimated by the net gain of nutrients in fish tissue.

\section{Nutrient assimilation}

The assimilation rates of $\mathrm{C}, \mathrm{N}$ and $\mathrm{P}$ were measured as scope for growth $\left(\mathrm{SFG}_{;} \mathrm{mg} \mathrm{h}^{-1}\right)$ for each element, which was defined as the difference between acquisition and expenditure. SFG of $\mathrm{C}, \mathrm{N}$ or $\mathrm{P}$ was calculated as: SFG $\left(\mathrm{mg} \mathrm{h}^{-1}\right)=\mathrm{AR}-$ respiration or excretion rate.

Oxygen consumption was converted to $\mathrm{C}$ excretion based on a mean respiratory quotient of $0.85: 1 \mathrm{mg}$ $\mathrm{O}_{2} \equiv 0.32 \mathrm{mg} \mathrm{C}$ (Martin 1993). Assuming that the average SFG values from monthly measurements were constant, the assimilation of nutrients by silver carp was estimated as: Assimilation $(\mathrm{mg})=\mathrm{SFG}$ $\left(\mathrm{mg} \mathrm{h}^{-1}\right) \times 24 \mathrm{~h} \times 30 \mathrm{~d}$.

\section{Statistical procedures}

To obtain functional relationships of physiological processes to environmental factors such as food con- ditions, temperature, DO level and transparency, a set of regression equations was fitted to experimental data following standard least-squares procedures. Regression analysis was applied by simple linear or non-linear procedures, depending on the most appropriate function to be fitted in each case (Zar 2009). Residuals were analyzed to check the normality and constant variance of predicted dependents. All statistical procedures were performed with SPSS for Windows Release 16.0.

\section{RESULTS}

\section{Environmental conditions and nutrient contents}

Temporal variations in environmental parameters, including temperature $\left(T_{;}{ }^{\circ} \mathrm{C}\right)$, dissolved oxygen $\left(\mathrm{DO}_{i} \mathrm{mg} \mathrm{l}^{-1}\right)$, transparency $\left(\mathrm{SD}_{;} \mathrm{cm}\right)$, food conditions (in terms of TPM $\left[\mathrm{mg} \mathrm{l}^{-1}\right.$ ], POM [mg l-1 ${ }^{-1}$, PIM [mg $\left.\mathrm{l}^{-1}\right]$ and organic content $\left[f_{;} \%\right]$ ) and nutrient contents including POC, PON and POP of the suspended particulate matter are listed in Table 1. Temperature underwent obvious temporal variations, with the highest value $\left(\sim 28.3^{\circ} \mathrm{C}\right)$ in July, decreasing afterward to the lowest $\left(\sim 23.4^{\circ} \mathrm{C}\right)$ in October. Because of high temperature and algae blooms in summer, DO levels and transparency remained at extremely low levels, especially in July and August. POM concentrations in July exhibited the highest values because of algal blooms. Owing to the feeding-driven re-suspension of particulate matter by silver carp, PIM concentrations in May and June were significantly higher than those in July and August, which led to the relatively

Table 1. Temporal changes in environmental conditions ( $T$, temperature; DO, dissolved oxygen; SD, transparency), food conditions (TPM, total particulate matter; POM, particulate organic matter; PIM, particulate inorganic matter; $f$, organic content) and nutrient content of suspended particulate matter (POC, particulate organic carbon; PON, particulate organic nitrogen; POP, particulate organic phosphorus). With the exceptions of $T$, DO and SD, data are presented as means \pm 1 SD (n $=8-9$ ). Different superscript letters within a row indicate a significant difference between monthly sampling dates in $2011(\mathrm{p}<0.05)$

\begin{tabular}{|lcccccc|}
\hline Parameter & May 20 & Jun 20 & Jul 20 & Aug 20 & Sep 20 & Oct 15 \\
\hline$T\left({ }^{\circ} \mathrm{C}\right)$ & 23.5 & 26.5 & 28.3 & 27.9 & 25.2 & 23.4 \\
DO $\left(\mathrm{mg} \mathrm{l}^{-1}\right)$ & 8.9 & 7.4 & 6.5 & 5.7 & 7.9 & 8.3 \\
SD $(\mathrm{cm})$ & 41.1 & 35.2 & 32.7 & 33.1 & 40.7 & 42.2 \\
TPM $\left(\mathrm{mg} \mathrm{l}^{-1}\right)$ & $39.30 \pm 2.11^{\mathrm{a}, \mathrm{b}}$ & $41.11 \pm 2.63^{\mathrm{b}}$ & $37.89 \pm 2.39^{\mathrm{a}, \mathrm{b}, \mathrm{c}}$ & $36.54 \pm 1.65^{\mathrm{a}, \mathrm{c}, \mathrm{d}}$ & $34.47 \pm 2.31^{\mathrm{c}, \mathrm{d}}$ & $32.96 \pm 1.44^{\mathrm{d}}$ \\
POM $\left(\mathrm{mg} \mathrm{l}^{-1}\right)$ & $14.72 \pm 1.14^{\mathrm{a}}$ & $15.54 \pm 1.75^{\mathrm{a}}$ & $22.32 \pm 1.56^{\mathrm{b}}$ & $20.87 \pm 1.58^{\mathrm{b}}$ & $13.37 \pm 1.01^{\mathrm{a}, \mathrm{c}}$ & $12.07 \pm 0.39^{\mathrm{c}}$ \\
PIM $\left(\mathrm{mg} \mathrm{l}^{-1}\right)$ & $24.58 \pm 2.06^{\mathrm{a}}$ & $25.57 \pm 2.75^{\mathrm{a}}$ & $15.58 \pm 3.12^{\mathrm{b}}$ & $15.67 \pm 4.14^{\mathrm{b}}$ & $21.10 \pm 2.38^{\mathrm{a}}$ & $20.89 \pm 1.41^{\mathrm{a}}$ \\
$f(\%)$ & $0.37 \pm 0.03^{\mathrm{a}}$ & $0.38 \pm 0.04^{\mathrm{a}}$ & $0.59 \pm 0.07^{\mathrm{b}}$ & $0.58 \pm 0.07^{\mathrm{b}}$ & $0.39 \pm 0.04^{\mathrm{a}}$ & $0.37 \pm 0.02^{\mathrm{a}}$ \\
POC $\left(\mu \mathrm{g} \mathrm{m}^{-1}\right)$ & $145.63 \pm 13.32^{\mathrm{a}, \mathrm{b}}$ & $151.39 \pm 12.71^{\mathrm{a}, \mathrm{b}}$ & $161.56 \pm 7.98^{\mathrm{a}}$ & $163.14 \pm 9.89^{\mathrm{a}}$ & $147.08 \pm 13.22^{\mathrm{a}, \mathrm{b}}$ & $138.89 \pm 10.77^{\mathrm{b}}$ \\
PON $\left(\mu \mathrm{gg}^{-1}\right)$ & $20.62 \pm 3.42^{\mathrm{ab}}$ & $25.81 \pm 2.12^{\mathrm{c}}$ & $24.62 \pm 3.40^{\mathrm{b}, \mathrm{c}}$ & $19.45 \pm 1.91^{\mathrm{a}}$ & $22.31 \pm 2.01^{\mathrm{a}, \mathrm{b}, \mathrm{c}}$ & $18.19 \pm 0.08^{\mathrm{a}}$ \\
POP $\left(\mathrm{gg} \mathrm{mg}^{-1}\right)$ & $1.75 \pm 0.08^{\mathrm{a}}$ & $2.18 \pm 0.03^{\mathrm{b}}$ & $3.08 \pm 0.11^{\mathrm{c}}$ & $1.89 \pm 0.07^{\mathrm{a}}$ & $2.30 \pm 0.15^{\mathrm{b}}$ & $1.09 \pm 0.07^{\mathrm{d}}$ \\
\hline
\end{tabular}


Table 2. Allometric relationship between clearance rate $\left(\mathrm{CR}_{\dot{i}} \mathrm{l} \mathrm{h}^{-1}\right)$ and body length $\left(\mathrm{BL}_{i} \mathrm{~cm}\right)$, and standardized clearance rates $\left(\mathrm{SCR}_{i}\right.$ $\mathrm{l} \mathrm{h}^{-1}$ ) of $30 \mathrm{~cm}$ silver carp Hypophthalmichthys molitrix. For SCR, data are presented as means $\pm 1 \mathrm{SD}$. Different superscript letters indicate a significant difference between monthly sampling dates in $2011(\mathrm{p}<0.05)$

\begin{tabular}{|lccccc|}
\hline $\begin{array}{l}\text { Sampling } \\
\text { date }\end{array}$ & Equation & $\mathrm{n}$ & $\mathrm{r}^{2}$ & $\mathrm{p}$ & $\mathrm{SCR}$ \\
\hline May 20 & $\mathrm{CR}=0.94 \times \mathrm{BL}^{0.74}$ & 8 & 0.65 & $<0.01$ & $11.77 \pm 0.59^{\mathrm{a}}$ \\
Jun 20 & $\mathrm{CR}=1.14 \times \mathrm{BL}^{0.75}$ & 5 & 0.40 & $<0.01$ & $14.24 \pm 0.92^{\mathrm{b}}$ \\
Jul 20 & $\mathrm{CR}=2.73 \times \mathrm{BL}^{0.52}$ & 9 & 0.65 & $<0.01$ & $15.69 \pm 0.71^{\mathrm{b}}$ \\
Aug 20 & $\mathrm{CR}=0.0059 \times \mathrm{BL}^{2.34}$ & 9 & 0.59 & $<0.01$ & $15.48 \pm 1.02^{\mathrm{b}}$ \\
Sep 20 & $\mathrm{CR}=0.67 \times \mathrm{BL}^{1.00}$ & 7 & 0.45 & $<0.01$ & $19.81 \pm 1.16^{\mathrm{c}}$ \\
Oct 15 & $\mathrm{CR}=0.39 \times \mathrm{BL}^{1.16}$ & 8 & 0.72 & $<0.01$ & $19.60 \pm 1.65^{\mathrm{c}}$ \\
\hline
\end{tabular}

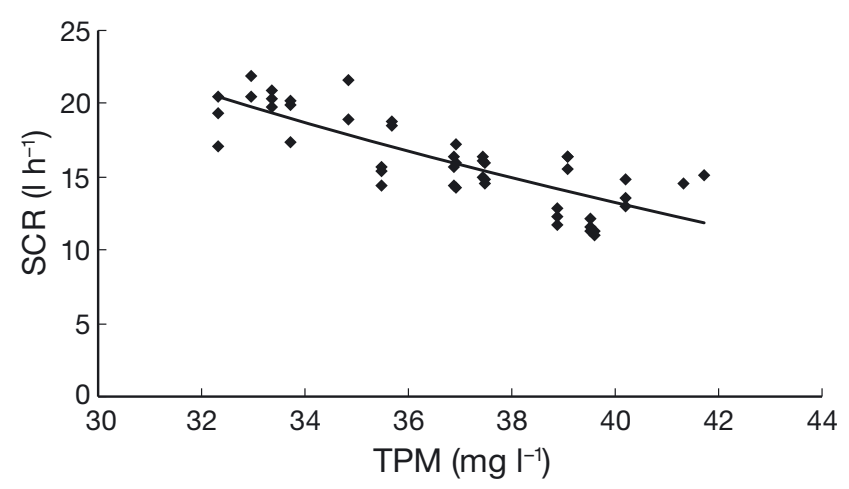

Fig. 2. Relationship between standardized clearance rate (SCR) of $30 \mathrm{~cm}$ silver carp Hypophthalmichthys molitrix and total particulate matter (TPM)

lower $f$. Seasonal changes in POC and PON showed a similar pattern to that of POM, with relatively higher values in summer (June to August) and lower values in spring (May) and autumn (September and October).

\section{Physiological rate}

In each of the 6 sampling months, the CRs of the experimental silver carp were significantly related to individual body length. The regressive allometric equations and the standardized CR (SCR) of a $30 \mathrm{~cm}$ individual for each sampling month are listed in Table 2.

As shown in Fig. 2, SCR was negatively related to food quantity in terms of TPM following the

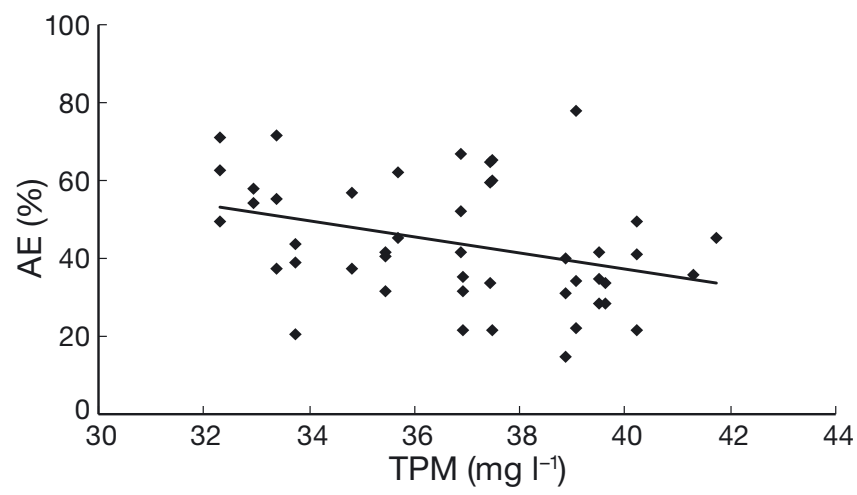

Fig. 3. Relationship between absorption efficiency (AE) of silver carp Hypophthalmichthys molitrix and total particulate matter (TPM)

equation: $\mathrm{SCR}=137.54-33.70 \times \ln \mathrm{TPM}\left(\mathrm{r}^{2}=0.66\right.$, $\left.F_{1,44}=64.51, \mathrm{p}<0.01\right)$. Standard filtration rate $(\mathrm{SFR})$ and standard filtration rate of POM (SOFR), were independent of TPM and organic content $(f)$.

As shown in Fig. 3, absorption efficiency (AE) was negatively related to TPM according to the linear regression model: $\mathrm{AE}=1.21-0.02 \times \mathrm{TPM}\left(\mathrm{r}^{2}=0.13\right.$, $\left.F_{1,44}=2.27, \mathrm{p}<0.05\right)$. Absorption rate (AR) was not significantly related to either food quantity (TPM) or food quality $(f)$, in spite of the decreasing AE with increasing TPM.

Oxygen consumption rate $\left(V_{\mathrm{O}_{2}}\right)$ was significantly related to the body length of silver carp following the allometric models. These models and the corresponding standardized oxygen consumption rate $\left(\mathrm{S}_{\mathrm{O}_{2}}\right.$; $\left.\mathrm{mg} \mathrm{h}^{-1}\right)$, as well as the standardized carbon respiration rate $\left(\mathrm{S} V_{\mathrm{C} i} \mathrm{mg} \mathrm{h}^{-1}\right)$ of a $30 \mathrm{~cm}$ silver carp for each monthly interval, are listed in Table 3 . The allometric relationships of nitrogen excretion rate $\left(V_{\mathrm{N}} \mu \mathrm{g} \mathrm{h} \mathrm{h}^{-1}\right)$ and phosphorus excretion rates $\left(V_{\mathrm{P}} \mu \mathrm{g} \mathrm{h}^{-1}\right)$ to body length, in addition to the corresponding standardized $V_{\mathrm{N}}\left(\mathrm{S} V_{\mathrm{N}} ; \mu \mathrm{g} \mathrm{h} \mathrm{h}^{-1}\right)$ and $V_{\mathrm{P}}\left(\mathrm{S} V_{\mathrm{P}} ; \mu \mathrm{g} \mathrm{h} \mathrm{h}^{-1}\right)$, are presented in Tables 4 \& 5, respectively.

Table 3. Allometric relationship between oxygen consumption rate $\left(V_{\mathrm{O}_{2}} ; \mathrm{mg} \mathrm{h}^{-1}\right)$ and body length $(\mathrm{BL} ; \mathrm{cm})$, and corresponding standardized oxygen consumption rate $\left(\mathrm{S} V_{\mathrm{O}_{2}} ; \mathrm{mg} \mathrm{h}^{-1}\right)$ and carbon respiration rate $\left(\mathrm{S} V_{\mathrm{C}} \mathrm{mg} \mathrm{h}^{-1}\right)$ of a $30 \mathrm{~cm}$ silver carp Hypophthalmichthys molitrix for each experimental month. For $\mathrm{S} V_{\mathrm{O}_{2}}$ and $\mathrm{S} V_{\mathrm{C}}$ data are presented as means $\pm 1 \mathrm{SD}$. Different superscript letters within each column indicate a significant difference between monthly sampling dates in $2011(\mathrm{p}<0.05)$

\begin{tabular}{|lcccccc|}
\hline Sampling date & Equation & $\mathrm{n}$ & $\mathrm{r}^{2}$ & $\mathrm{p}$ & $\mathrm{S} V_{\mathrm{O}_{2}}\left(\mathrm{mg} \mathrm{h}^{-1}\right)$ & $\mathrm{S} V_{\mathrm{C}}\left(\mathrm{mg} \mathrm{h}^{-1}\right)$ \\
\hline May 20 & $V_{\mathrm{O}_{2}}=0.75 \times \mathrm{BL}^{1.01}$ & 9 & 0.34 & $<0.01$ & $22.39 \pm 1.35^{\mathrm{a}}$ & $7.17 \pm 0.43^{\mathrm{a}}$ \\
Jun 20 & $V_{\mathrm{O}_{2}}=4.04 \times \mathrm{BL}^{0.57}$ & 9 & 0.58 & $<0.01$ & $27.34 \pm 1.15^{\mathrm{b}}$ & $8.75 \pm 0.37^{\mathrm{b}}$ \\
Jul 20 & $V_{\mathrm{O}_{2}}=0.07 \times \mathrm{BL}^{1.68}$ & 8 & 0.55 & $<0.01$ & $18.53 \pm 0.92^{\mathrm{c}}$ & $5.93 \pm 0.30^{\mathrm{c}}$ \\
Aug 20 & $V_{\mathrm{O}_{2}}=0.34 \times \mathrm{BL}^{1.16}$ & 9 & $0.71<0.01$ & $17.15 \pm 1.01^{\mathrm{c}}$ & $5.49 \pm 0.32^{\mathrm{c}}$ \\
Sep 20 & $V_{\mathrm{O}_{2}}=0.04 \times \mathrm{BL}^{1.87}$ & 8 & 0.78 & $<0.01$ & $22.06 \pm 0.83^{\mathrm{a}}$ & $7.06 \pm 0.27^{\mathrm{a}}$ \\
Oct 15 & $V_{\mathrm{O}_{2}}=0.16 \times \mathrm{BL}^{1.45}$ & 9 & 0.62 & $<0.01$ & $20.47 \pm 0.96^{\mathrm{a}}$ & $6.55 \pm 0.31^{\mathrm{a}}$ \\
\hline
\end{tabular}


Table 4. Allometric relationship between nitrogen excretion rate ( $V_{\mathrm{N}} ; \mu \mathrm{g}$ $\mathrm{h}^{-1}$ ) and body length $\left(\mathrm{BL}_{;} \mathrm{Cm}\right)$, and corresponding standardized nitrogen excretion rate $\left(\mathrm{S} V_{\mathrm{N}} i \mu \mathrm{g} \mathrm{h}^{-1}\right)$ of a $30 \mathrm{~cm}$ silver carp Hypophthalmichthys molitrix for each experimental month. For $\mathrm{S} V_{\mathrm{N}}$, data are presented as means $\pm 1 \mathrm{SD}$. Different superscript letters indicate a significant difference between monthly sampling dates in $2011(\mathrm{p}<0.05)$

\begin{tabular}{|llcccc|}
\hline Sampling date & Equation & $\mathrm{n}$ & $\mathrm{r}^{2}$ & $\mathrm{p}$ & $\mathrm{S} V_{\mathrm{N}}\left(\mu \mathrm{g} \mathrm{h} \mathrm{h}^{-1}\right)$ \\
\hline May 20 & $V_{\mathrm{N}}=14.79 \times \mathrm{BL}^{0.89}$ & 9 & 0.64 & $<0.01$ & $297.28 \pm 30.74^{\mathrm{a}}$ \\
Jun 20 & $V_{\mathrm{N}}=103.17 \times \mathrm{BL}^{0.65}$ & 9 & 0.76 & $<0.01$ & $920.65 \pm 15.58^{\mathrm{b}}$ \\
Jul 20 & $V_{\mathrm{N}}=1.57 \times \mathrm{BL}^{1.75}$ & 8 & 0.60 & $<0.01$ & $571.04 \pm 26.19^{\mathrm{c}}$ \\
Aug 20 & $V_{\mathrm{N}}=10.20 \times \mathrm{BL}^{1.24}$ & 8 & 0.73 & $<0.01$ & $656.91 \pm 17.73^{\mathrm{d}}$ \\
Sep 20 & $V_{\mathrm{N}}=0.78 \times \mathrm{BL}^{1.83}$ & 7 & 0.91 & $<0.01$ & $368.36 \pm 8.07^{\mathrm{e}}$ \\
Oct 15 & $V_{\mathrm{N}}=1.59 \times \mathrm{BL}^{1.44}$ & 8 & 0.58 & $<0.01$ & $201.38 \pm 9.66^{\mathrm{f}}$ \\
\hline
\end{tabular}

Table 5. Allometric relationship between phosphorus excretion rate ( $V_{\mathrm{P}} ; \mu \mathrm{g}$ $\mathrm{h}^{-1}$ ) and body length (BL; $\mathrm{Cm}$ ), and corresponding standardized phosphorus excretion rate $\left(\mathrm{SV}_{\mathrm{P}} \mu \mathrm{g} \mathrm{h}^{-1}\right)$ of a $30 \mathrm{~cm}$ silver carp Hypophthalmichthys molitrix for each experimental month. For $\mathrm{S} V_{\mathrm{P}}$, data are presented as means $\pm 1 \mathrm{SD}$. Different superscript letters indicate a significant difference between monthly sampling dates in 2011 ( $p<0.05)$

\begin{tabular}{|lccccr|}
\hline Sampling date & Equation & $\mathrm{n}$ & $\mathrm{r}^{2}$ & $\mathrm{p}$ & $\mathrm{S} V_{\mathrm{P}}\left(\mu \mathrm{g} \mathrm{h}^{-1}\right)$ \\
\hline May 20 & $V_{\mathrm{P}}=2.40 \times \mathrm{BL}^{0.74}$ & 9 & 0.64 & $<0.01$ & $28.98 \pm 2.50^{\mathrm{a}}$ \\
Jun 20 & $V_{\mathrm{P}}=0.89 \times \mathrm{BL}^{1.46}$ & 9 & 0.43 & $<0.01$ & $122.17 \pm 9.59^{\mathrm{b}}$ \\
Jul 20 & $V_{\mathrm{P}}=0.26 \times \mathrm{BL}^{1.70}$ & 8 & 0.61 & $<0.01$ & $81.57 \pm 3.62^{\mathrm{c}}$ \\
Aug 20 & $V_{\mathrm{P}}=0.025 \times \mathrm{BL}^{2.22}$ & 9 & 0.54 & $<0.01$ & $45.82 \pm 3.12^{\mathrm{d}}$ \\
Sep 20 & $V_{\mathrm{P}}=0.0015 \times \mathrm{BL}^{2.90}$ & 7 & 0.42 & $<0.01$ & $26.42 \pm 4.60^{\mathrm{a}}$ \\
Oct 15 & $V_{\mathrm{P}}=0.0025 \times \mathrm{BL}^{2.42}$ & 8 & 0.73 & $<0.01$ & $9.03 \pm 2.33^{\mathrm{e}}$ \\
\hline
\end{tabular}

\section{DISCUSSION}

Previous studies reported that the feeding process of fish was affected by numerous environmental factors, i.e. food availability (food quantity, in terms of TPM; food quality, in terms of POM and $f$ ), temperature, DO level, etc. (Stoner 2004, Lall \& Tibbetts 2009, Vanella et al. 2012, Smith \& Sanderson 2013). The relationship of SCR to TPM showed that food availability was the dominant factor affecting the feeding process of silver carp. The negative relationship of SCR to food quantity in terms of TPM suggests the presence of preingestive regulation in silver carp in response to changes in food availability. With decreasing TPM, silver carp might actively regulate feeding behavior to maintain feeding quantity, such as opening the mouth gape, resulting in more water passing the oral cavity, increasing swimming speed, closing the gill arches to let water pass unfiltered, etc. Like the active regulation of clearance rate, filtration rate could be kept independent of food conditions. Turker et al. (2003) found that the filtration rate of silver carp

$\mathrm{N}$ and $\mathrm{P}$ excretion rates were temporally synchronic, with higher metabolic rates in summer (June, July and August) and lower in other months. Oxygen consumption rate appears lower values in July and August, and the highest values in June. As shown in Fig. $4, \mathrm{~S} V_{\mathrm{O}_{2}}, \mathrm{~S} V_{\mathrm{N}}$ and $\mathrm{S} V_{\mathrm{P}}$ were significantly correlated with temperature according to the following equations: $\mathrm{S} V_{\mathrm{O}_{2}}=-600.3+49.1 T-0.96 T^{2}\left(\mathrm{r}^{2}=0.54\right.$, $\left.F_{2,50}=101.14, \mathrm{p}<0.01\right) ; \mathrm{S} V_{\mathrm{N}}=-32665+2497 T-$ $46.67 T^{2}\left(\mathrm{r}^{2}=0.72, F_{2,47}=1439.1, \mathrm{p}<0.01\right)$; and $\mathrm{S} V_{\mathrm{P}}=$ $0.00001 \mathrm{~T}^{8.38}\left(\mathrm{r}^{2}=0.55, F_{1,48}=594.2, \mathrm{p}<0.01\right)$.

\section{Nutrient assimilation}

Net budgets of the nutrients, including $\mathrm{C}, \mathrm{N}$ and $\mathrm{P}$, which were represented by scope for growth (SFG), and the total assimilation of the 3 nutrients by silver carp are summarized in Table 6. SFGs in July and August appeared lower values relative to other months (June and September). The total nutrient assimilation capacities of individual silver carp for $\mathrm{C}_{\text {, }}$ $\mathrm{N}$ and $\mathrm{P}$ during the culturing period were 236.86 , 37.70 and $3.67 \mathrm{~g}$, respectively. increased to the maximum value and remained constant as suspended POC in the water column increased. In the present study, absorption rate was not related to TPM or $f$, and together with the downregulation of $\mathrm{AE}$ with increasing TPM, this indicates the presence of a post-ingestive regulative function in the feeding processes.

The metabolic rate of fish generally depends on numerous factors such as feeding habit, DO levels and temperature (Kutty 1972, Schurmann \& Steffensen 1997, Wood 2001, Mallekh \& Lagardère 2002). In the present study, the oxygen consumption rate and corresponding carbon respiration rate demonstrated an obvious temporal pattern. As indicated by the regressive model shown in Fig. 4A, the oxygen consumption rate of Hypophthalmichthys molitrix in the present study was significantly affected by water temperature. Previous studies showed that fish fed more vigorously and specific dynamic action (SDA) was accelerated as temperature increased within the thermal tolerance range, which would result in a high oxygen consumption rate (Aguiar et al. 2002, Lermen et al. 2004, Pang et al. 2010, Zhao et al. 2011a). In the present study, the oxygen consumption 

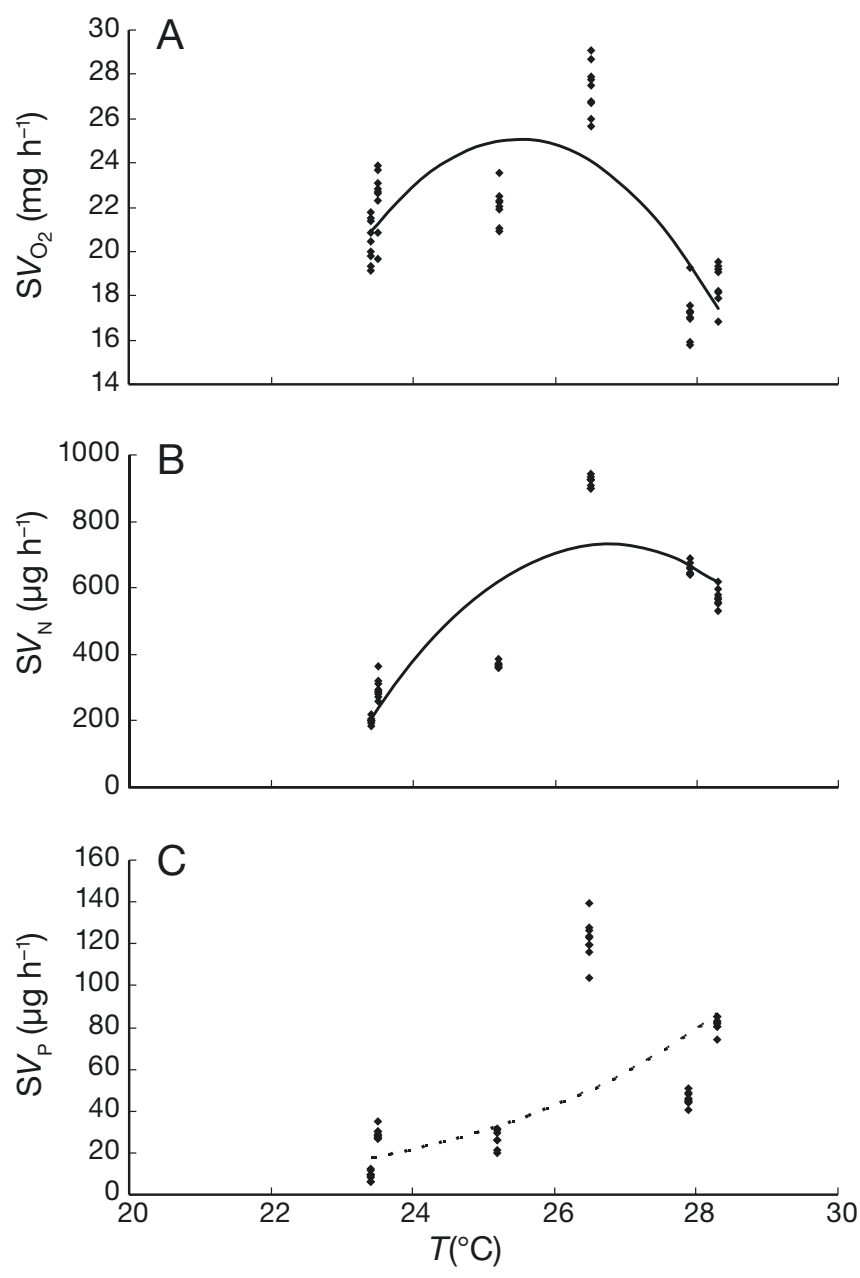

Fig. 4. (A) Standardized oxygen consumption rate $\left(\mathrm{S} V_{\mathrm{O}_{2}}\right)$ versus water temperature $(T)$. (B) Standardized nitrogen excretion rate $\left(\mathrm{S} V_{\mathrm{N}}\right)$ versus water temperature. (C) Standardized phosphorus excretion rate $\left(\mathrm{S} V_{\mathrm{P}}\right)$ versus water temperature

Table 6. Net budget rate (scope for growth [SFG]) and total assimilation of carbon, nitrogen and phosphorus by a silver carp Hypophthalmichthys molitrix individual at monthly intervals during the experimental period in 2011

\begin{tabular}{|c|c|c|c|c|c|c|}
\hline \multirow[t]{2}{*}{$\begin{array}{l}\text { Sampling } \\
\text { date }\end{array}$} & \multicolumn{3}{|c|}{$\begin{array}{c}\text { SFG } \\
\left(\mathrm{mg} \mathrm{h}^{-1} \text { ind }^{-1}\right)\end{array}$} & \multicolumn{3}{|c|}{$\begin{array}{l}\text { Assimilation } \\
\quad\left(\mathrm{g} \text { ind } .^{-1}\right)\end{array}$} \\
\hline & $\mathrm{C}$ & $\mathrm{N}$ & P & $\mathrm{C}$ & $\mathrm{N}$ & $\mathrm{P}$ \\
\hline May 20 & 31.48 & 4.39 & 0.41 & 22.67 & 3.16 & 0.29 \\
\hline Jun 20 & 55.32 & 9.53 & 0.98 & 39.83 & 6.86 & 0.71 \\
\hline Jul 20 & 40.35 & 7.26 & 0.80 & 29.05 & 5.23 & 0.57 \\
\hline Aug 20 & 45.59 & 6.32 & 0.77 & 32.82 & 4.55 & 0.55 \\
\hline Sep 20 & 85.25 & 13.82 & 1.36 & 61.38 & 9.95 & 0.98 \\
\hline \multirow[t]{3}{*}{ Oct 15} & 70.99 & 11.04 & 0.237 & 51.11 & 7.95 & 0.56 \\
\hline & \multicolumn{3}{|c|}{ Average SFG } & \multicolumn{3}{|c|}{ Total assimilation } \\
\hline & 54.83 & 8.73 & 0.85 & 236.86 & 37.70 & 3.67 \\
\hline
\end{tabular}

rates of $H$. molitrix decreased despite the increasing temperatures in July and August, which might be due to the physiological inhibition caused by the relatively lower DO level. This result is similar to that of related studies on other teleost fish species (Rantin \& Johansen 1984, Fernandes et al. 1995). In addition, Crocker \& Cech (1997) reported that hypoxia significantly depressed the oxygen consumption rates of white sturgeon Acipenser transmontanus at all temperatures and body sizes. Zhao et al. (2011b) showed that under the conditions of elevated temperature and hypoxia, silver carp showed an anti-filtering response, i.e. decreased oxygen consumption and associated lower feeding rates in terms of SCR and SFR.

$\mathrm{N}$ and $\mathrm{P}$ excretion rates of silver carp exhibited positive correlations with temperature in the present study. Excretion rates of both $\mathrm{N}$ and $\mathrm{P}$ increased in summer, which might be induced by the following two mechanisms. First, the increased metabolic demands in response to the elevated temperature were partially met by means of deamination of amino acids and catabolism of phospholipids (Forsberg \& Summerfelt 1992). Jobling (1981) reported that excretion rates of young plaice (Pleuronectes platessa L.) increased with increasing temperature. Second, glycogen reserves and synthesis were unavailable under conditions of low oxygen levels, while more protein and lipid were exploited as internal energy sources. A study by Kutty (1972) showed the increased anaerobic energy utilization and protein metabolism of Tilapia at low oxygen levels, which might be of advantage for preventing acidosis.

SFGs of $\mathrm{C}, \mathrm{N}$ and $\mathrm{P}$ showed temporal changes during the experimental period, and decreased in July and August accompanied with the elevated temperature and lower DO levels. Silver carp showed the positive values of nutrient assimilation, indicating that they could efficiently accumulate nutrients throughout the experimental period. Xia et al. (2013c) reported that food sources of silver carp included POM, residue of fish feed and fish feces in coculture ponds of grass carp and silver carp. Accordingly, the direct nutrient removal by silver carp from farming wastes including feed residue and fish feces were $91.19,14.51$ and $1.41 \mathrm{~g}$ per individual for $\mathrm{C}, \mathrm{N}$ and $\mathrm{P}$, respectively. In contrast, uptake of POM by silver carp further implied the potential of the indirect removal of dissolved nutrients, because the growth of microalgae, which was the principal constituent of POM, accumulated a considerable amount of dissolved nutrients from the water column. As such, the co-culture of silver carp with grass carp can effectively relieve the nutrient pollution due to the release 
of farming wastes in the forms of feed residue and fish excreta. Moreover, additional culture of silver carp improved the utilization of food resources in the aquaculture waters and increased the industrial benefit. Such polyculture systems containing various species belonging to different feeding guilds hence provide an economic and environmental win-win resolution scheme to reduce organic pollution and enhance aquaculture production.

Acknowledgements. The work described in this paper was funded by a grant from the National Basic Research Program of China ('973' Program).

\section{LITERATURE CITED}

Ackefors H, Enell M (1994) The release of nutrients and organic matter from aquaculture systems in Nordic countries. J Appl Ichthyol 10:225-241

Aguiar LH, Kalinlin AK, Rantin FT (2002) The effects of temperature on the cardio-respiratory function of the neotropical fish Piaractus mesopotamicus. J Therm Biol 27:299-308

Ballestrazzi R, Lanari D, Agaro ED (1998) Performance, nutrient retention efficiency, total ammonia and reactive phosphorus excretion of growing European sea-bass (Dicentrarchus labrax, L.) as affected by diet processing and feeding level. Aquaculture 161:55-65

Burke JS, Bayne DR, Rea H (1986) Impacts of silver and bighead carp on plankton communities of channel catfish ponds. Aquaculture 55:59-68

Cao L, Wang W, Yang Y, Yang C, Yuan Z, Xiong S, Diana J (2007) Environmental impact of aquaculture and countermeasures to aquaculture pollution in China. Environ Sci Pollut Res Int 14:452-462

Chen SL, Liu XF, Hua L (1991) The role of silver carp and bighead in the cycling of nitrogen and phosphorus in the East Lake ecosystem. Acta Hydrobiol Sin 15:8-26

Cranford PJ, Grant G (1990) Particle clearance absorption of phytoplankton and detritus by the sea scallop Placopecton magellanicus (Gmelin). J Exp Mar Biol Ecol 137: 105-121

Crocker CE, Cech JJ Jr (1997) Effects of environmental hypoxia on oxygen consumption rate and swimming activity in juvenile white sturgeon, Acipenser transmontanus, in relation to temperature and life intervals. Environ Biol Fishes 50:383-389

Dong SL, Li DS, Bing XW, Shi QF, Wang F (1992) Suction volume and filtering efficiency of silver carp (Hypophthalmichthys molitrix Val.) and bighead carp (Aristichthys nobilis Rich.). J Fish Biol 41:833-840

Fernandes MN, Barrionuevo WR, Rantin FT (1995) Effects of thermal stress on respiratory responses to hypoxia of South American prochilodontidae fish, Prochilodus scrofa. J Fish Biol 46:123-133

Forsberg JA, Summerfelt RC (1992) Effect of temperature on diel ammonia excretion of fingerling walleye. Aquaculture 102:115-126

Fukushima M, Takamura N, Sun L, Nakagawa M, Matsushige K, Xie P (1999) Changes in the plankton community following introduction of filter-feeding planktivo- rous fish. Freshw Biol 42:719-735

Gao QF, Cheung KL, Cheung SG, Shin PKS (2005) Effects of nutrient enrichment derived from fish farming activities on macroinvertebrate assemblages in a subtropical. Mar Pollut Bull 51:994-1002

Gao QF, Shin PKS, Lin GH, Chen SP, Cheung SG (2006) Stable isotopic and fatty acid evidence for uptake of organic wastes by green-lipped mussels Perna viridis in a polyculture fish farm system. Mar Ecol Prog Ser 317:273-283

Gao QF, Xu WZ, Liu XS, Cheung SG, Shin PKS (2008) Seasonal changes in $\mathrm{C}, \mathrm{N}$ and $\mathrm{P}$ budgets of green-lipped mussels Perna viridis and removal of nutrients from fish farming in Hong Kong. Mar Ecol Prog Ser 353:137-146

Gophen M, Tsipris Y, Meron M, Bar-Ilan I (2003) The management of Lake Agmon wetlands (Hula Valley, Israel). Hydrobiologia 506-509:803-809

Gowen RJ, Ezzi I, Rosenthal H, Maekinen T (1990) Environmental impact of aquaculture activities. European Aquaculture Society Special Publication, Ghent, p 257-283

Jobling M (1981) Some effects of temperature, feeding and body weight on nitrogenous excretion in young plaice Pleuronectes platessa L. J Fish Biol 18:87-96

Kadir A, Kundu RS, Milstein A, Wahab MA (2006) Effects of silver carp and small indigenous species on pond ecology and carp polycultures in Bangladesh. Aquaculture 261: 1065-1076

Ke ZX, Xie P, Guo LG, Liu YQ, Yang H (2007) In situ study on the control of toxic Microcystis blooms using phytoplanktivorous fish in the subtropical Lake Taihu of China: a large fish pen experiment. Aquaculture 265:127-138

Kestemont P (1995) Different systems of carp production and their impacts on the environment. Aquaculture 129: 347-372

Kutty MN (1972) Respiratory quotient and ammonia excretion in Tilapia mossambica. Mar Biol 16:126-133

Lall SP, Tibbetts SM (2009) Nutrition, feeding, and behavior of fish. Vet Clin North Am Exot Anim Pract 12:361-372

Lermen CL, Lappe R, Crestani M, Vieira VP and others (2004) Effect of different temperature regimes on metabolic and blood parameters of silver catfish Rhamdia quelen. Aquaculture 239:497-507

Leung KMY, Chu JCW, Wu RSS (1999) Effects of body weight, water temperature and ration size on ammonia excretion by the areolated grouper (Epinephelus areolatus) and mangrove snapper (Lutjanus argentimaculatus). Aquaculture 170:215-227

Lin CK, Yi Y (2003) Minimizing environmental impacts of freshwater aquaculture and reuse of pond effluents and mud. Aquaculture 226:57-68

Mallekh R, Lagardère JP (2002) Effect of temperature and dissolved oxygen concentration on the metabolic rate of the turbot and the relationship between metabolic scope and feeding demand. J Fish Biol 60:1105-1115

Martin KLM (1993) Aerial release of $\mathrm{CO}_{2}$ and respiratory exchange ratio in intertidal fishes out of water. Environ Biol Fishes 37:189-196

MOAC (Ministry of Agriculture, China) (2013) China fisheries yearbook (2012) China Agriculture Publisher, Beijing

Muir JF (1982) Recirculated water systems in aquaculture. In: Muir JF, Roberts RJ (eds) Recent advances in aquaculture. Croom Helm, London, p 357-446

Packard GC, Boardman TJ (1987) The misuse of ratios to scale physiological data that vary allometrically with body size. In: Feder ME, Bennett AF, Burggern WW, 
Huey RB (eds) New directions in ecological physiology. Cambridge University Press, Cambridge, p 216-239

Pang X, Cao ZD, Peng JL, Fu SJ (2010) The effects of feeding on the swimming performance and metabolic response of juvenile southern catfish, Silurus meridionalis, acclimated at different temperatures. Comp Biochem Physiol A 155:253-258

Pillay T (2007) Aquaculture and the environment, 2nd edn. Blackwell, Rome.

Rantin FT, Johansen K (1984) Responses of the teleost Hoplias malabarieus to hypoxia. Environ Biol Fishes 11:221-228

Schurmann H, Steffensen JF (1997) Effects of temperature, hypoxia and activity on the metabolism of juvenile Atlantic cod. J Fish Biol 55:1166-1180

Smith DW (1989) The feeding selectivity of silver carp, Hypophthalmichthys molitrix Val. J Fish Biol 34:819-828

Smith JC, Sanderson SL (2013) Particle retention in suspension-feeding fish after removal of filtration structures. Zoology 116:348-355

Starling FLRM (1993) Control of eutrophication by silver carp, Hypophthalmichthys molitrix, in the tropical Paranoa Reservoir (Brasilia, Brazil): a mesocosm experiment. Hydrobiologia 257:143-152

Starling FLRM, Rocha AJA (1990) Experimental study of the impacts of planktivorous fishes on plankton community and eutrophication of a tropical Brazilian reservoir. Hydrobiologia 200-201:581-591

Stoner AW (2004) Effects of environmental variables on fish feeding ecology: implications for the performance of baited fishing gear and stock assessment. J Fish Biol 65: 1445-1471

Strychar KB, MacDonald BA (1999) Impacts of suspended particle on feeding and absorption rates in cultured eastern oysters (Crassostrea virginica, Gmelin). J Shellfish Res 18:437-444

Tucker CS (2006) Low-density silver carp Hypophthalmichthys molitrix (Valenciennes) polyculture does not prevent cyanobacterial off-flavours in channel catfish Ictalurus punctatus (Rafinesque). Aquacult Res 37:209-214

Turker H, Eversole AG, Brune DE (2003) Comparative Nile tilapia and silver carp filtration rates of Partitioned Aquaculture System phytoplankton. Aquaculture 220:449-457

Editorial responsibility: Adam Hughes,

Oban, UK
Vanella FA, Boy CC, Fernandez DA (2012) Temperature effects on growing, feeding, and swimming energetic in the Patagonian blennie Eleginops maclovinus (Pisces: Perciformes). Polar Biol 35:1861-1868

Wood CM (2001) Influence of feeding, exercise, and temperature on nitrogen metabolism and excretion. Fish Physiol 20:201-238

Xia B, Gao QF, Li HM, Dong SL, Wang F (2013a) Turnover and fractionation of nitrogen stable isotope in tissues of grass carp Ctenopharyngodon idella. Aquacult Environ Interact 3:177-186

Xia B, Gao QF, Dong SL, Wang F (2013b) Carbon stable isotope turnover and fractionation in grass carp Ctenopharyngodon idella tissues. Aquat Biol 19:207-216

Xia B, Gao QF, Dong SL, Shin PKS, Wang F (2013c) Uptake of farming wastes by silver carp Hypophthalmichthys molitrix in polyculture ponds of grass carp Ctenopharyngodon idella: evidence from $\mathrm{C}$ and $\mathrm{N}$ stable isotopic analysis. Aquaculture 404-405:8-14

Xie P, Liu JC (2001) Practical success of biomanipulation using filter-feeding fish to control cyanobacteria blooms: a synthesis of decades of research and application in a subtropical hypereutrophic lake. ScientificWorldJournal 1:337-356

Yan LL, Zhang GF, Liu QG, Li JL (2009) Optimization of culturing the freshwater pearl mussels, Hyriopsis cumingii with filter feeding Chinese carp (bighead carp and silver carp) by orthogonal array design. Aquaculture 292: 60-66

Yang SD, Liou CH, Liu FG (2002) Effects of dietary protein level on growth performance, carcass composition and ammonia excretion in juvenile silver perch (Bidyanus bidyanus). Aquaculture 213:363-372

Zar JH (2009) Biostatistical analysis, 5th edn. Prentice Hall, Upper Saddle River, NJ

Zhao ZG, Dong SL, Wang F, Tian XL, Gao QF (2011a) Respiratory response of grass carp (Ctenopharyngodon idella) to temperature changes. Aquaculture 322-323:128-133

Zhao ZG, Dong SL, Wang F, Tian XL, Gao QF (2011b) The measurements of filtering parameters under breathing and feeding of filter-feeding silver carp (Hypophthalmichthys molitrix Val.). Aquaculture 319:178-183

Submitted: May 9, 2016; Accepted: July 6, 2016

Proofs received from author(s): August 3, 2016 